\title{
The effects of legal versus business education on decision making in public administrations with a Weberian tradition
}

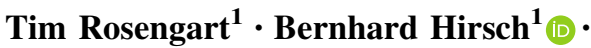 \\ Christian Nitzl $^{1}$ (D)
}

Received: 22 November 2017/ Accepted: 10 October 2018/Published online: 19 October 2018

(C) The Author(s) 2018

\begin{abstract}
We analyse the socialization effects of a university education on decision making in a public-sector context with a Weberian tradition. The results of our vignette study of 331 law and business students and 155 professionals in German public administrations show that business students-in contrast to law studentsmake decisions significantly more in line with private-sector logic. This phenomenon is not observed for professionals. Individuals' transformations from student to professional status appear to be affected by particularly strong internal and external pressures to socialize, which widely neutralizes the differences between legal and business professionals.
\end{abstract}

Keywords University education - Socialization · Public administration · Weberian tradition Decision making

\section{Introduction}

In many European countries, a legalistic-bureaucratic logic for steering public administrations still predominates (Boltanski and Thévenot 2006; Pina et al. 2009). Its key idea is the "legal state", which is accompanied by a social market economy and its corresponding welfare state (Pollitt and Bouckaert 2017). For such a context,

Bernhard Hirsch

bernhard.hirsch@unibw.de

Tim Rosengart

Tim.rosengart@law-school.de

Christian Nitzl

christian.nitzl@unibw.de

1 University of the German Armed Forces Munich, Werner-Heisenberg-Weg 39, 85577

Neubiberg, Germany 
good governance is expected to be ensured by the basic principle of legality ("Legalitätsprinzip"), which permits administrative activity exclusively on the basis of laws and results in a strong focus on the legal and procedural correctness of each individual administrative act (Meyer and Hammerschmid 2006). To achieve this objective, the roots of which go back to the ideas of Max Weber (1922/1978), the state has traditionally relied on employing an enormous proportion of public servants who hold university degrees in law (e.g. Veit and Scholz 2016; Sager et al. 2012; Hammerschmid and Meyer 2005).

While public service motivation (PSM) and its impact on the decision making of (future) public servants have been studied quite intensively over the past last decades (e.g. for Wright et al. 2017; Pedersen 2013; Clerkin and Coggburn 2012; $\mathrm{Ng}$ and Gossett 2013; Rose 2012; Liu et al. 2011; Vandenabeele 2008), the effect of university education on (future) public servants' decision making has been analysed, if at all, only as a control variable. Vandenabeele (2008) found that academics who have studied law are more attracted by the public administration as a potential employer than individuals who graduated in business/economics; he explicitly argued that "within government, education is an important variable" (p. 1102). Vandenabeele (2008) speculated about only the reasons for the impact of university education on public servants' decision making but expects that prospective employees are probably "looking for a match between their abilities (education) and the organizational demands" (p. 1102).

From an institutional theory perspective, organizational demands can be traced back to different institutional logics, which typically coexist in public-sector institutions. Such competing logics are likely to cause trade-offs between the performance dimensions of public institutions. For the public and non-profit sectors, the literature distinguishes between a logic emphasizing service delivery to its citizens and a logic geared towards results, efficiency, effectiveness and managerial competence (Doherty et al. 2014; Skelcher and Smith 2015; McPherson and Sauder 2013; Meyer and Hammerschmid 2006). In our study, we call the first mentioned logic community logic and the second private-sector logic.

We adopt Vandenabeele 's (2008) claim to further elaborate on the impact of academic education on public servants' decision-making behaviours. We thereby do not focus on an (often) once-in-a-lifetime decision (job choice) but on the specific recurrent scenarios with which public servants are confronted when they work in the public sector. More concretely, we analyse the impact of law versus business university education on students' and practitioners' decision making in the publicsector workday setting.

To our knowledge, previous studies that analysed the effects of education on the decision making of public servants focused only on the impact of short-term training for public servants (Kroll and Moynihan 2015; Witesman and Wise 2012; Cavalluzzo and Ittner 2004). We assume that a multi-year, full-time university education has a greater impact on an individual's values and his/her mindset than short-term training programmes completed after joining the workforce of public institutions. We tie this idea to the argument of Christensen and Lægreid (2009) and Christensen et al. (2012) such that the personal background of a civil servant, which has been formed at least partly by his/her university education, can have greater 
relevance in influencing his/her behaviour than the organizational structure of the public institution or the cultural experiences of the actors (for a similar categorization, see Broucker 2010).

While public management studies examining the impact of public servants' multi-year university educations on their decision making are quite scarce, the stream of education literature in which the impact of an economics versus legal education on decision making has been analysed is rather sophisticated (e.g. Kahneman et al. (1986a , b); Rubinstein 2006; Cipriani et al. 2009). So far, however, it is unknown whether the findings of the afore-mentioned studies can be transferred to the context of public institutions and their employees, which is a critical issue for public management research (O'Toole and Meier 2015).

We focus on German public administrations as a particular working environment because they are a good representation of the legalistic-bureaucratic logic (Sager et al. 2012; Meyer et al. 2014; Kuhlmann 2010; Kuhlmann et al. 2008; Meyer and Hammerschmid 2006).

The remainder of our article is structured as follows. First, we review the key characteristics of legal and business education and the structure, principles and objectives of the German public administration. Subsequently, four research hypotheses are derived. In the following section, we describe the research design, the dataset and the results of our study. Finally, we discuss our findings, their contributions to the existing literature and the consequences for practice.

\section{Institutional setting}

Kuhlmann and Wollmann (2013) classified the German public administration as a typical example of a continental-European federal system. Pollitt and Bouckaert (2017) described the German system of public administration "by the classic bureaucratic model with strong emphasis on legality and proper fulfilment of regulatory functions" (p. 298). Founded in Max Weber's rational-legal form of authority (Weber 1922/1978), the main task of a public administration is defined as the politically neutral and independent translation of political will into administration practice (Ziller 2012).

Because of the greater and more demanding expectations of citizens, local governments in particular have especially been under pressure to introduce more advanced services. This pressure has led to modernization initiatives and the promotion of new management ideas, especially at the local level. Many cities and counties have, therefore, implemented the ideas of the "New Steering Model", which promotes a clear distinction of responsibilities among politics and administration, contract management, and a focus on output control. The reform initiatives at the federal level have been few (Pollitt and Bouckaert 2017).

Kuhlmann and Wollmann (2013) reported that in Germany, because of its federal structure, no central institution for the education of elite public servants exists. The training of public servants is executed in a strongly decentralized manner under the responsibility of the states (Länder), which have their own schools for public 
administration affairs. ${ }^{1}$ In these schools, the education of future employees for non(higher) management positions ("mittlerer/gehobener Dienst") is strongly oriented towards a law-specific content and the learning of law-specific expertise (Kuhlmann and Wollmann 2013). In contrast, trainees for senior official careers are typically recruited from German universities. Because of the legalistic culture of administration, lawyers are privileged in the recruitment for senior positions (Kuhlmann and Wollmann 2013). Nevertheless, business graduates are also recruited systematically by many ministries or local administrations. ${ }^{2}$

As summarized in Table 1, legal education in Germany is focused on preparing students for traditional legal careers in the judiciary (judges/prosecutors), law firms (lawyers) and public administration. Hence, the examination and study policies of law faculties at German universities note that law students must be taught to apply legal texts from a "judge's point of view" (e.g. Ludwig-Maximilians-Universität München 2012).

Neither the German Judiciary Act nor the rules and regulations for legal education in the 16 federal states (e.g. Bayerische Ausbildungs- und Prüfungsordnung für Juristen 2018) stipulate that law students must be prepared for the economic choices that they will frequently face in their future profession.

Table 1 shows that, quite different from legal education in Germany, business education in Germany faces far less regulation. However, the examination and study policies for business studies at various German universities show that all faculties that offer an education in business administration focus on teaching their students the efficient use of resources and prepare them for jobs in which they must compete in a market economy (e.g. Ludwig-Maximilians-Universität München 2008). To achieve this objective, business students receive an education that provides them with the skills and knowledge that they need to create successful products and services. In addition to subjects such as finance, accounting and marketing, most curricula contain obligatory courses in microeconomics. A more detailed investigation into the official descriptions of the aforementioned courses reveals that every graduate with an education in business administration should have obtained all the relevant skills and knowledge to make decisions that are correct from the viewpoint of microeconomic theory.

\footnotetext{
1 These schools typically have the status of a University of Applied Sciences. Only a few public management programs at the university level are offered, e.g. by Freiburg University (http://www. studium.uni-freiburg.de/de/studienangebot/master/info/413), Potsdam University (https:/www.unipotsdam.de/studium/studienangebot/masterstudium/master-a-z/master-of-public-management-masterweiterbildend.html), Hertie School of Government (https://www.hertie-school.org/de/studium/executivemaster-of-public-administration/), Kassel University (https://www.uni-kassel.de/uni/studium/ masterstudium/oeffentliches-managementpublic-administration-master/), Speyer University (http:// www.uni-speyer.de/de/studium/public-administration/profil.php), and Bundeswehr University Munich (https://www.unibw.de/casc). Typically, these programs link knowledge from administration sciences and business administration. Thereby, they offer insights into both community logic and private sector logic.

2 E.g. the German Federal Ministry of Finance (https://www.bundesfinanzministerium.de/Content/DE/ Standardartikel/Ministerium/Arbeiten-Ministerium-Geschaeftsbereich/Arbeiten-Ministerium/ terminhinweise-jobmessen.html) and the German Federal Ministry of Economic Affairs and Energy (https://www.bmwi.de/Redaktion/DE/Textsammlungen/Ministerium/bewerbungsinfos.html) systematically recruit lawyers and business/economics graduates for their trainee programs. In these ministries, there is no systematic recruitment of graduates from Public Management Schools.
} 
Table 1 The defining characteristics of legal and business education

\begin{tabular}{ll}
\hline Legal education & Business education \\
\hline $\begin{array}{c}\text { Objectives, content, structure and final } \\
\text { examinations are defined by federal and state } \\
\text { laws and are highly standardized }\end{array}$ & No legal standards \\
$\begin{array}{c}\text { Focus on preparing students for traditional legal } \\
\text { careers in the judiciary (judges/prosecutors), law } \\
\text { firms (lawyers) and public administration }\end{array}$ & $\begin{array}{c}\text { Focus on preparing students for jobs in firms, } \\
\text { which must compete in a market economy }\end{array}$ \\
$\begin{array}{c}\text { Students are taught to apply legal texts from a } \\
\text { judge's point of view. All legal texts are enacted } \\
\text { by legislation that must adhere to the principles } \\
\text { of a "social federal state" }\end{array}$ & $\begin{array}{c}\text { Students are taught how to make efficient decisions } \\
\text { under conditions of scarcity } \\
\text { Students are taught how to create products and } \\
\text { services that will succeed in a market economy } \\
\text { No introduction to microeconomic theory or the } \\
\text { concept of economic efficiency }\end{array}$ \\
$\begin{array}{c}\text { Students are taught skills and knowledge that are } \\
\text { correct from the viewpoint of microeconomic } \\
\text { theory }\end{array}$ \\
\hline
\end{tabular}

Microeconomics textbooks commonly describe their objective as helping students to develop economic intuition and encouraging their readers to develop the distinctive mindset known as "thinking like an economist" (Frank 2013, p. vii). Economists are expected to make economically efficient choices that result from "the direct comparison of the advantages [benefits] and disadvantages [costs] of several alternatives in the set of possible choices [scarcity]" (Lanteri and Rizzello 2009, p. 902). This definition of what constitutes economically efficient decision making from the perspective of microeconomic theory can be applied to any economic problem and, therefore, to the context of public administration.

\section{Conceptual framework and hypotheses}

\subsection{Socialization effects during university education (education effect)}

Bandura (1977) argued that individuals learn through either the consequences of their own behaviour or the observation of relevant, existing models. The existing literature defines socialization within a group as the result of learning from the consequences of one's own behaviour (Kolb 1981; Allinson and Hayes 1988; Cockerton et al. 2002; Bright and Graham 2015). Following Lüthje (2008), we assume that, in the context of university education, exam results and students' relationships with professors or fellow students allow individuals who study law or business to assess the progress of their socialization in the discipline that they have chosen. Learning through observation is the process by which the existing models influence decision makers' thoughts and behaviours. In this process, not only individuals with formal and informal powers (e.g. professors, tutors, successful graduates) but also learning materials (e.g. books, lecture slides) are important (Bandura 1977). 
The particularities of legal and business studies that have been previously discussed indicate that law and business students' learning processes are guided by distinctive models that modify their personal characteristics in accordance with the key principles of their respective disciplines. The German Judiciary Act (2017) is particularly important in the context of legal education because it specifies the content (i.e. compulsory and elective courses) and structure (i.e. state examinations) of law students' education. Furthermore, it defines the preparation of law students for traditional legal careers in the judiciary field (judges/prosecutors), law firms (lawyers) and general jobs in a legalistic public administration as the ultimate goal of their education. Similarly, the compulsory two-year practical training, which follows the first state examination, should have a significant impact on law students' learning experience because it consists of practical and theoretical parts and introduces students to the practices of court adjudication (judge), administration (employee in the public administration) and legal advice (attorney at law). Finally, the learning materials used in German law institutions can also be understood as models. In the context of our research, it is important to understand that these materials teach students how to apply legal texts and their underlying principles but fail to address the economic consequences of these decisions.

During their studies, law students are not confronted with business models. Additionally, Pedersen (2013) found that, among law students, the correlation between their attitudes towards "public interest" and their willingness to work in the public sector is greater magnitude than that of students of economics. Both phenomena indicate that law students are expected to be guided by models that prioritize the principles of "public interest" over economic concerns. In contrast, business students are primarily influenced by models that highlight the importance of making economically efficient choices under conditions of scarcity. This type of socialization is very close to what is known as the private-sector logic. In this context, it is not surprising that the learning materials for business administration students are aligned with the overarching principle of economic efficiency.

Considering the models that shape law students' learning processes, their decision choices at the end of their studies must be expected to be less in accordance with the logic of microeconomic theory, whereas the decision making of senior business students should be more in line with economic thinking. This expectation leads us to the formulation of our first hypothesis:

$\mathrm{H}_{1}$ : Senior law students make decisions less in accordance with private-sector logic than senior business students.

\subsection{Socialization effects after joining public institutions}

When graduates become employees of a specific public administration, they should be motivated to increase the personal congruence between themselves and the other members of their organizations, i.e. their internal willingness to socialize (Vandenabeele 2008). In this context, socialization can be understood as a process that modifies and adapts existing personal characteristics through constant interaction with the work environment (Schein 2003). Individuals typically either 
modify their existing skills or develop new skills, knowledge, capabilities, values and attitudes during this process through practice and learning (Festinger 1957).

Additionally, external pressure from an organization to socialize is a force whereby the organization attempts to integrate its new members. In this context, individuals learn through consequences by assessing positive and negative experiences with previous decisions, forming the basis for future adjustments to their behaviours (Christensen and Lægreid 2009; Lüthje 2008). In particular, feedback from superiors allows new employees to assess their degree of socialization within a new organization. Similarly, by learning through observation, individuals are influenced by formal and informal powers, as well as formally fixed guidelines and laws (Bandura 1977).

Individuals' internal willingness to socialize and the external pressure to socialize are similar in that they relate to subjects' ambitions to maximize their own utility (Katz 2004). Subjects exert efforts to increase their congruence of their personal values with the values of the organizations for which they work to achieve happiness (Ambrose et al. 2008; Vandenabeele 2008; Cha et al. 2014). Such an internal willingness of new employees of the German public administration is expected to be high because the individuals voluntarily decided to enter into this career. $^{3}$

Because of the generally high level of regulation and the hierarchical structures that exist in all organizations of the German public administration, its employees should also feel a comparably strong external pressure to socialize. Therefore, we assume that, in a hierarchy-driven environment, superiors with formal powers are likely to act as role models for new employees, who are provided with feedback from their superiors (Püttner 2007; Lüthje 2008).

External pressure to socialize in public institutions seems to express itself in a Weberian legalistic culture in which decision makers must strictly comply with relevant laws and impartially execute the political will of the legislative branch of government. Because the legalistic culture of German bureaucracies is closely linked to the social welfare principle of the German Basic Law (Püttner 2007) and because of the aforementioned dominance of law graduates in German bureaucracies, we expect that the German public administration still focuses more on public interest and less on economic efficiency. Considering that the models (e.g. legal texts, judges, superiors during their practical training) that guide law students' decision making are identical to those that would shape their decisions as public servants, law school graduates' decision making can still be expected to be mainly influenced by the idea of serving the public interest, as these students were trained during their law studies (Pedersen 2013).

\footnotetext{
3 We believe that this argument is strong in a situation of a job market with low unemployment rates, such as in Germany. Additionally, in many public institutions, the requirements to work as a lawyer or business graduate are high. See, therefore, e.g. the requirements of the German Federal Ministry of Finance (https://www.bundesfinanzministerium.de/Content/DE/Standardartikel/Ministerium/ArbeitenMinisterium-Geschaeftsbereich/Arbeiten-Ministerium/terminhinweise-jobmessen.html) and the German Federal Ministry of Economic Affairs and Energy (https://www.bmwi.de/Redaktion/DE/ Textsammlungen/Ministerium/bewerbungsinfos.html).
} 
Nevertheless, it must be considered that public servants are confronted by budget constraints in their daily work. This lack of available funds sets limitations on the discretionary powers of employees in the German public administration, which could prevent them from fully implementing the logic of "public interest". Hence, former law students who decide to follow a career in this work environment should perceive it as necessary to adjust their decision choices to the economic realities that are likely to restrict all decision makers in the German public administration. Therefore, we propose the following hypothesis:

$\mathrm{H}_{2}$ : Senior law students make decisions less in accordance with private-sector logic than legal professionals in the German public administration.

In contrast, we have illustrated that business studies are heavily focused on teaching students how to make decisions that are efficient from the perspective of microeconomic theory. Nevertheless, when business graduates apply for a job in public administration, they are also confronted with the guiding principles of the "legal state". Thus, they must balance values such as efficiency, effectiveness, responsiveness or equity when making their decisions (Blair and Janousek 2014). How these decisions are made depends on the environment in which the decision makers are embedded, which can be described as the "political culture in which they operate" (Blair and Janousek 2014, 484). According to Elazar (1972), political culture includes "the set of perceptions of what politics is and what can be expected from government, held by both the general public and the politicians" (p. 90). Consequently, business graduates who have chosen to join a public employer should feel a particularly strong need to adjust their values and their cognitive biases to the rationality that characterizes their work environment. In this context, the legalistic culture of the German public administration is important because it could imply pressure on the employees to socialize and to change their values in the direction of a legalistic and welfare-oriented logic, leading us to the formulation of hypothesis $\mathrm{H}_{3}$ :

$\mathrm{H}_{3}$ : Senior business students make decisions more in accordance with privatesector logic than professionals in the German public administration who have studied business administration.

With reference to Van de Walle and Bovaird (2007), Broucker (2015) argued that the organization for which a public servant works has an influence on the use of his/ her knowledge. Knowledge that better meets the needs of the organization will have a greater likelihood of being used.

The needs of an organization are mainly reflected by the dominating institutional logic of the organization. Bearing in mind that, in Germany, community logic is still predominant, we expect a potential conflict between the individual business knowledge of business graduates and the trade-off between the community logic of the organization. Weighing the educational effects of studying business administration against the power of the classic community logic, with its strong emphasis on legality and public interest, leads us to the assumption that community logic should dominate but not erase the models that guide its employees' decision making. Therefore, for German public administrations, we expect minor differences between 
the economic choices of professionals with legal and business backgrounds. To test this assumption, we formulate hypotheses $\mathrm{H}_{4}$ :

$\mathrm{H}_{4}$ : Legal professionals in the German public administration make decisions less in accordance with private-sector logic than professionals who have studied business administration.

While only few of the afore-mentioned contributions used control variables, most of them argued that decision makers' gender has the largest influence on the economic choices of the subjects who participated in their surveys. For example, Rubinstein (2006) "observed more compassionate behavior among women" (p. C7). In contrast, the previous finding was not supported by Cipriani et al. (2009), who found indifference between male and female respondents with regard to their behaviour in the survey question of Rubinstein (2006). Nevertheless, the authors found evidence for a gender effect in the context of the "snow shovel" survey question of Kahneman et al. (1986a), indicating that female respondents consider price increases as unfair "more often than male students and they seem to be more reluctant to apply demand-based pricing" (Cipriani et al. 2009, 465). Similarly, they can also replicate the same effect with the help of the previously discussed survey question from Kahneman et al. (1986b). Overall, the existing empirical evidence suggests that decision makers' gender is likely to impact their decision making, although there is disagreement about the direction of this influence. Thus, as the empirical evidence from previous studies suggests, we include sex as a control variable in our research model.

\section{Study design and data}

Since German legal education focuses on teaching students the correct application of the laws, whereas the education of business students is aimed at teaching students how to make economically efficient choices under conditions of scarcity, the operationalization of our research hypotheses focuses on measuring subjects' choices in situations that require a trade-off between community logic and privatesector logic. Because this study has the objective of exploring socialization's effects on decision making in the German public administration, the operationalization of our four research hypotheses must adapt to the particularities of this decisionmaking context.

We used vignettes to test the decision-making behaviours of our participants. Vignettes are an instrument that has already been used in public management research (e.g. Ossege 2012; Walker et al. 2013; Grimmelikhujsen and Proumbescu 2017; Olsen 2017). Vignettes are "short descriptions of a person or social situation that contain precise references to what are thought to be the most important factors in the decision-making or judgment-making processes of respondents" (Alexander and Becker 1978, p. 94). Because, in our setting, we focus on the impact of education and job status (student vs. employee) on financial decision making, the two independent variables were not manipulated in the case descriptions because they are variables related directly to the participants' personalities. Manipulation of 
the independent variables would be typical for a classical experiment. Therefore, we describe our experiment as a quasi-experiment. Vignette (quasi-)experiments are characterized as being appropriate for analysing the influence of a social context on individual decisions and behaviours (Kunz and Linder 2012; Taylor 2006). They allow for the examination of personal aspects otherwise not directly observable (Kunz and Linder 2012). In our case, the influence of education and the impact of the organizational environment in which the individuals are embedded can be analysed. Using a within-subjects design, we confronted all participants with three vignettes. This approach allows us to collect data about decision making from all participants in three different situations (Taylor 2006, p. 1197; Wallander 2009, p. 506) and to test their decision-making behaviours according to fairness/equity vs. efficiency issues (similar to Walker et al. 2013).

The first vignette was adopted from Kahneman et al. (1986a). It demands that participants establish programme activities, which is, therefore, a typical task for public managers (Kroll and Moynihan 2015, p. 420). It allows us to measure decision makers' perceived fairness of the market mechanism ("market case"). Similarly, the decision-making problem from Kahneman et al. (1986b), which we used as a basis for our second vignette, appears to be a reliable measure of individuals' preference for specific resource allocation mechanisms ("allocation case"), which is also a relevant question in public institutions (Kroll and Moynihan 2015, p. 420). The two decision-making cases are similar because respondents must weigh their pro-market orientation and the corresponding relevance of efficiency against social concerns (i.e. fairness, equity). Our third vignette was adopted from Rubinstein (2006) because it measures decision makers' preferences for profit maximization.

Research into a database of all past decisions of the Munich city council supported the selection of our vignettes because it revealed that professionals in the German public administration must address similar problems on a regular basis (Kreisverwaltungsreferat der Landeshauptstadt München 2010; Personal- und Organisationsreferat der Landeshauptstadt München 2014; Sozialreferat der Landeshauptstadt München 2014). The practical relevance of necessary modifications has been proved and was inspired by expert interviews conducted with 15 researchers and five senior officials of the German public administration in May 2012. The adjusted decision-making cases are displayed in the Appendix of this text (Tables 4, 5, 6).

In line with Lüthje (2008), Cipriani et al. (2009) and Brosig et al. (2010), we used a survey design that incorporates our previously discussed decision-making cases to generate a dataset that allows us to empirically test the research hypotheses of this study.

To achieve the maximum level of participation across student populations, an author of this study appeared during lectures by selected professors, read aloud a standardized welcome note that focused on organizational matters and the anonymity of participants' answers, and then, together with the lecturer, distributed the questionnaire to the class. Respondents from our six populations required $17 \mathrm{~min}$, on average, to complete the questionnaire, which, after completion, could be dropped off anonymously in boxes located next to the doors of the students' 
classrooms. To control for externalities and to increase the comparability of our student samples, we decided to distribute our survey among only students from the faculties of law and business at the Ludwig-Maximilians-Universität Munich, which is one of the leading universities in Germany and offers both legal and business studies. Senior students were surveyed at the beginning of the fifth semester because it represented the last chance to survey the maximum number of individuals before students from both disciplines must specialize in selected areas of their academic discipline (e.g. criminal law, finance). The survey was distributed to our two student samples at the start of the winter semester in October 2012.

We administered an online-based survey in December and January 2012/13. Decision makers in the German public administration work at the municipal, state or federal level. Following this objective, our survey was primarily sent to professionals with legal and business backgrounds who were working for the City of Munich, the Federal Ministry of Economics and Technology, and the Bavarian State Ministry of Economics, Infrastructure, Transport and Technology (formerly the Ministry for Economics, Infrastructure, Transport and Technology). The three aforementioned administrations were chosen for our surveys of professionals because these individuals face decisions related to our decision-making cases more often than individuals in other organizations within the German public administration. ${ }^{4}$ Furthermore, the aforementioned institutions are particularly relevant because they employ comparably large shares of professionals with business backgrounds.

For reasons of comparability, professionals were asked whether they are working at the federal, state or municipal level. A total of $14 \%$ of our surveyed professionals were working at the federal level, $46 \%$ at the state level and $40 \%$ at the municipal level. The status of the employees in the German public administration varies. Of the surveyed individuals, $78 \%$ were officials [Beamte], whereas $22 \%$ were working as regular employees [Angestellte des Öffentlichen Dienstes]. Our two samples of professionals appear to be representative for the total workforce of the German public administration (Deutsches Statistisches Bundesamt 2013). The working experience of the professionals who participated in the survey for this text ranged from 1 to 42 years. On average, the participants had worked for more than 9 years.

Table 2 illustrates the sample size for each of the four populations that participated in the survey for this text.

As Table 2 shows, the sample consisted of 106 senior students in law (SL), 225 senior business students (SB), 121 professionals with law backgrounds (PL), and 34 professionals with business backgrounds (PB). The number of professionals with business backgrounds is relatively small. However, Campbell et al. (1995) and Man et al. (2000) illustrated that the differences between the sizes of our sample do not deter the empirical findings of the research. Of our participants, $45 \%$ are men and $55 \%$ are women. Men and women are quite similarly distributed across the groups.

\footnotetext{
${ }^{4}$ E.g. the Bavarian State Ministry of Economics, Infrastructure, Transport and Technology describes its policy as "promoting[.] sustainable economic growth with the objective of securing and expanding economic prosperity in all regions of the country. The guiding principle is the social market economy. It combines entrepreneurial freedom, economic strength, ability to change and social responsibility" (www. stmwi.bayern.de/en).
} 
Table 2 Dataset for the empirical analysis of this text

\begin{tabular}{llc}
\hline Sample & Abbreviation & Sample size \\
\hline 5th semester law students & $(=\mathrm{SL})$ & 106 \\
5th semester business students & $(=\mathrm{SB})$ & 225 \\
Professionals with law backgrounds & $(=\mathrm{PL})$ & 121 \\
Professionals with business backgrounds & $(=\mathrm{PB})$ & 34 \\
Total & & 486 \\
\hline
\end{tabular}

The highest percentage of men $(56.8 \%)$ can be found in the professionals' group with business backgrounds (PB). The average age of the participants is 28.9 years old (median 23 years).

\section{Results}

For the analysis of the data, we used a partial least squares factorial structural equation modelling (PLS FAC-SEM) approach. This approach allows to assess whether and how model relationships vary as a function of an underlying factorial design (Streukens and Leroi-Werelds 2016b). In our case, the factors are the different groups, and the dependent variables are the answers for the three cases. We used the senior law students as the baseline group. The advantage of using PLS FAC-SEM is that it is possible to test the influence of the groups on all three cases in a singular model (Nitzl 2016). In addition, it is also possible with this approach to control our results for the effect of sex. To test the group differences, we used a twotailed $t$ test based on 500 accelerated bias-corrected bootstraps (Streukens and Leroi-Werelds 2016a).

As illustrated in Fig. 1, research hypothesis $\mathrm{H}_{1}$ suggests that the effect of legal and business studies expresses itself at the end of the education through measurable differences between the economic choices of senior law and senior business students. To test $\mathrm{H}_{1}$, law and business students must be compared at the end of their educations with regard to their choices in our three decision-making cases. Our second and third research hypotheses propose that socialization's effects influence individuals' economic choices during their transformation from student to professional. To test $\mathrm{H}_{2}$ and $\mathrm{H}_{3}$, senior law (business) students and professionals with a law (business) background in the German public administration must be compared with regard to their choices in our three decision-making cases. Our last research hypothesis proposes that differences exist among professionals who work for the German public administration that must be attributed to their educational backgrounds in legal or business studies. To test $\mathrm{H}_{4}$, professionals from both academic backgrounds must be compared with regard to their economic choices in our three decision-making cases. 
Fig. 1 Summary of the research hypotheses and the required dataset for testing them
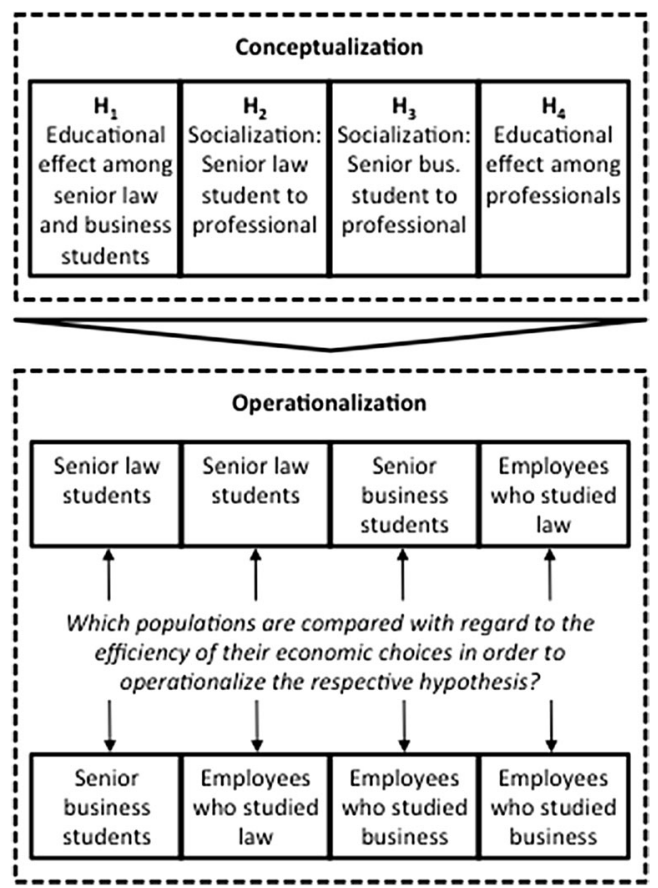

Table 3 Path coefficients (first line) and $p$ values (second line)

\begin{tabular}{lccc}
\hline & $\begin{array}{l}\text { Kahneman et al. (1986a) } \\
\text { "market case" }\end{array}$ & $\begin{array}{l}\text { Kahneman et al. (1986b) } \\
\text { "allocation case" }\end{array}$ & $\begin{array}{l}\text { Rubinstein (2006) } \\
\text { "profit case" }\end{array}$ \\
\hline $\mathrm{H}_{1}$ & $\mathbf{0 . 1 3 9}$ & $\mathbf{0 . 2 7 9}$ & $\mathbf{0 . 2 3 3}$ \\
& 0.013 & 0.000 & 0.000 \\
$\mathrm{H}_{2}$ & 0.025 & $-\mathbf{0 . 2 8 0}$ & -0.080 \\
& 0.676 & 0.000 & 0.132 \\
$\mathrm{H}_{3}$ & $\mathbf{0 . 1 1 8}$ & $\mathbf{0 . 0 9 9}$ & $\mathbf{0 . 1 8 7}$ \\
& 0.046 & 0.088 & 0.001 \\
$\mathrm{H}_{4}$ & 0.021 & $\mathbf{0 . 1 8 1}$ & 0.046 \\
& 0.685 & 0.000 & 0.363 \\
Control & $\mathbf{0 . 1 3 3}$ & $\mathbf{0 . 1 0 3}$ & 0.010 \\
“sex" & 0.002 & 0.014 & 0.817 \\
\hline
\end{tabular}

Table 3 summarizes the results of the hypothesis testing for each of the three decision-making cases. The first lines are the path coefficients and the second lines show the $p$ values. Significant path coefficients are indicated in bold.

Hypothesis $\mathrm{H}_{1}$ proposes that senior students with a legal studies background make decisions less in accordance with a private-sector logic than senior students with a business studies background. Significant differences were found for the 
market cases $(0.139 ; p=0.013)$, for their preference for a mechanism to allocate scarce resources $(0.279 ; p=0.000)$, and for the profit orientation $(0.233$; $p=0.000)$. In all cases, law school graduates made decisions less in accordance with a private-sector logic than subjects who graduated from business studies.

Research hypotheses $\mathrm{H}_{2}$ and $\mathrm{H}_{3}$ were designed to investigate the effect of socialization during subjects' transformation from students to professionals. In this context, research hypothesis $\mathrm{H}_{2}$ proposes that the decisions of subjects with legal backgrounds are less in accordance with a private-sector logic than those of legal professionals, while $\mathrm{H}_{3}$ suggests that the choices of subjects with business backgrounds are less in accordance with a private-sector logic as a result of socialization's effects, which affect subjects' transformation from students to professionals. Hypothesis $\mathrm{H}_{2}$ is only partially supported, as we found differences between senior law students and legal professionals only with regard to their choices in our "allocation case" $(-0.280$; $p=0.000)$. In the context of the other decision cases, the "market case" $(0.025$; $p=0.676)$ and the "profit case" $(-0.080 ; p=0.132)$, we found no significant path coefficient, suggesting that socialization occurs only in the case of "allocation". In contrast to $\mathrm{H}_{2}$, we were able to fully support $\mathrm{H}_{3}$, as significant differences between senior business students and professionals with business backgrounds regarding the "market case" $(0.118 ; p=0.046)$, the "allocation case" $(0.099 ; p=0.088)$, and the "profit case" $(0.187 ; p=0.001)$ could be observed. The business students' decisions in these cases were more in line with a private-sector logic than those of professionals with a business background.

Only in the "allocation case" $(0.181 ; p=0.000)$ were significant differences found between employees of the German public administration who studied law and those who studied business chosen for the operationalization of hypotheses $\mathrm{H}_{4}$. Overall, this result indicates that only in the "allocation case" do professionals with a business background make decisions that are more in line with a private-sector logic than professionals with a law background. In the other two cases, professionals with a business background converged with professionals with a law background.

The results were controlled for the effect of sex. We found that, for both the "market case" $(-0.133 ; p=0.002)$ and the "allocation case" $(-0.103 ; p=0.014)$, women's decisions were significantly less in line with a private-sector logic. 5

\section{Discussion and conclusions}

Our results showed that socialization's effects, as a result of university education, matter in a public-sector-specific decision-making context. While Kroll and Moynihan (2015) found that training activities partly create a performancemanagement-specific capacity for public servants, we provide empirical evidence for an effect of university education on performance-related decision making in a public-sector context. Our results show that senior law students and senior business

\footnotetext{
5 Furthermore, we tested years of work (age) as a control variable. There was no significant effect on any of the three cases that we tested. There were also no changes in the results of the hypotheses testing. Hence, we do not show these results in detail for brevity reasons.
} 
students significantly differ with regard to their choices in the "allocation case", the "profit case", and the "market case", which have all been framed for a public-sector decision-making context. In all cases, senior law students made decisions less in accordance with a private-sector logic than senior business students. Linking these results to the research of Kroll and Moynihan (2015), we argue that, during university studies, individuals learn routines that will be consequently executed in making decisions within a public-sector setting.

Reflecting on our findings from the background of disillusioning cases of the implementation of performance-management-driven steering of public institutions in Central Europe (Kuhlmann 2010; Ongaro and Valotti 2008; Kuhlmann et al. 2008; Capano 2003), the preferential treatment of lawyers in the recruitment of future senior officials (Kuhlmann and Wollmann 2013) can be interpreted as one explanation for this lack of implementation. Our results thereby implicate the findings of Hammerschmid and Meyer (2005), who linked the existence of a "relatively high scepticism regarding the transferability of management concepts and the extremely limited managerial autonomy within the administration [...] with the high percentage of public executives with a legal background" (p. 729) in Austria.

Our findings partly differ from previous education studies conducted outside a public management context. Cipriani et al. (2009) previously reported on the decision making of senior business students and their results suggested that socialization's effects during a university education have a strong impact on the choices of the students in both the "market case" and the "allocation case". This finding concerning the "market case" and the "allocation case" is in line with our results of testing $\mathrm{H}_{1}$. However, while the empirical evidence that we derived from our samples shows that the choices of business students in the "allocation case" become more efficient as a result of socialization's effects, the results of Cipriani et al. (2009) imply that business students make less correct decisions as a result of their educations. In contrast with our results, Cipriani et al. (2009) did not find evidence for a socialization effect concerning the "profit case".

Our results indicate that senior business students are consequent in using privatesector logic for all decision tasks, even in the public-sector context. Therefore, business students transfer their learning from business studies, even to a publicsector decision-making context. Because business students typically do less care about "public interest" (Pedersen 2013), they seem to have no problem using a basic economic rule for making decisions in such an untypical context. This result provides some indication that the socialization effect of a multi-year business education in German universities is quite powerful.

Hypotheses $\mathrm{H}_{2}$ and $\mathrm{H}_{3}$ were designed to investigate the effect of socialization during subjects' transformations from students to professionals. In this context, research hypothesis $\mathrm{H}_{2}$ suggests that the economic decisions of law professionals are more in accordance with a private-sector logic than the decisions of senior law students, while $\mathrm{H}_{3}$ proposes that the economic choices of business professionals are less in accordance with a private-sector logic than those of senior business students as a result of socialization's effects, which cause subjects' transformations from students to professionals. 
Our empirical findings show partial differences in the decision making of professionals with legal backgrounds compared to senior law students and in that of professionals with business backgrounds compared to senior business students. While there is a difference in decision making in the "allocation case" for law professionals, the decision making of legal experts does not differ according to the "market case" and the "profit case". In contrast, in all three decision cases, business professionals decide significantly differently from senior business students after joining public administrations. For them, private-sector logic as a rule for their decision making has apparently become less relevant.

The above findings show a strong socialization effect for business graduates after joining public administrations. This result is not surprising because, with reference to Schein (2003), we would expect that subjects who start careers in the German public administration will face the crucial task of maximizing the congruence between themselves and their work environments (i.e. fellow employees, superiors, laws, principles). In this context, in line with Lüthje (2008), new employees' internal willingness to socialize should be very high because they have intentionally chosen a job in public administration and because they naturally desire to belong to this particular social entity. Furthermore, graduates who choose jobs in the German public administration are confronted by a generally high level of regulation and hierarchical structures characterizing their new work environment, which still must be described-especially for German ministries-as typical for "classic bureaucratic organizations" (Veit and Scholz 2016, p. 6). Because of the generally high level of regulation and the hierarchical structure that exists in all organizations of the German public administration, its employees can be expected to feel comparably strong external pressure to socialize. Our empirical findings show that this pressure is especially the case for professionals with business backgrounds when they must balance profit maximization and the layoffs of workers. In this case, the legalistic tradition and the aforementioned orientation towards the public interest of German administrations seem to force decision makers, even those with business educations, to overweight the social dimension of their decision cases. Here, it seems that the culture, i.e. the laws, principles, structures and objectives that characterize the decision-making environment of the German public administration, is more powerful than the educational backgrounds of its employees and-for business graduates-their willingness to implement a performance-based-steering culture. Corresponding to our findings, Veit and Scholz (2016) confirmed the high pressure to socialize for non-lawyers in German public institutions.

Nevertheless, professionals with a law background partly seem to realize that public institutions are confronted by financial pressures, and resources must be allocated efficiently under the real-life condition of scarcity. Therefore, the law professionals changed their decision making in the "allocation case" to a more management-oriented logic.

Concerning the "allocation case", business professionals make decisions that are even more in line with a private-sector logic than do law professionals. Both findings concerning the "allocation case" can be explained at least partly by German public administrations-similar to all EU member countries-having to abide by very detailed and sophisticated public procurement laws, by which central, 
regional and local governments and public authorities, bodies and agencies are governed (Amann et al. 2014; Aschhoff and Sofka 2009). Public procurement means spending public money in an efficient and effective (i.e. focused on targets) manner, and the public procurement process itself is "intended as a rigid process narrowly aimed at non-discrimination, cost efficiency and the achievement of transparency goals" (Amann et al. 2014, p. 353, referring to EU 2004). Thereby, EU procurement laws ask for a regulated target-related allocation mechanism, which has become part of the legal system of public institutions that consequently must be implemented in the member states. Because of its rigidity, implementing binding public procurement legislation fits the legalistic logic of public administrations and forces public servants with legal educational backgrounds to focus on cost efficiency aspects in procurement settings. It also allows professionals with a business background to use the decision-making rules that they learned during their university educations more intensively. In contrast, neither making a profit nor laying off workers is explicitly forced by European or national public laws.

Our results show that women decide significantly less in line with a private-sector logic concerning the "market case" and the "allocation case". This finding fits the assumption of Rubinstein (2006) that women show more compassionate behaviour and are less confident in the market. Our result could provide a further indication that women have stronger values that correspond to social concerns than men (Croson and Gneezy 2009).

Our findings show the relevance of institutional logics in a public-sector context and the impact of university education for such a context. The prevailing culture in a public administration seems to outshine the effect of university education. Human resource managers in public institutions should be aware of this phenomenon. When senior managers are planning to base administrative decision making more on private-sector logic, they must change the culture of the organization to a corresponding institutional logic. Our findings also indicate the need for and practical relevance of public management study programmes at (German) universities. These programmes intensively address the described trade-off between private-sector and community logic in public institutions and its consequences for steering them (see, for similar ideas, Denhardt 2001). Our findings should also motivate public institutions to systematically hire these graduates from public management study programmes when recruiting new trainees.

This study does not come without limitations. First, social desirability might distort our empirical results. In this case, respondents do not state their real opinions but provide answers in accordance with social norms (Raab-Steiner and Benesch 2012). For example, respondents' answers to the survey questions of Rubinstein (2006) could be biased because this construct creates a situation that confronts decision makers with the difficult decision of allocating scarce resources and explicitly introduces the moral dilemma, which is a result of such a process. Similar to previous studies, this text has attempted to reduce potential biases from social desirability by avoiding unnecessarily emotional formulations, and our particular efforts were directed at meeting participants' concerns about the confidentiality and anonymity of their data (Busz et al. 1972; Goossens and Méon 2010). Second, although we invested considerable effort into translating the vignettes of Kahneman 
et al. (1986a , b) and Rubinstein (2006) from a private- into a public-sector context, there is also a risk that, for some respondents, the described decision contexts appeared somewhat artificial and different from real-life decision making, which could have led to somewhat distorted results (Kunz and Linder 2012). Third, our study focuses on decision making by public employees in the German public administration. Although our sample groups should represent their overall populations relatively well, generalizations from our findings must be drawn with caution because our previous discussion is based on choices observed from students of one university and professionals from only three organizations of the German public administration. As already mentioned, the German administration is one representative example of a bureaucratic-legalistic organization. Therefore, our survey results could differ from research in other countries with different histories and cultures within their administrations. Future studies could focus on this cultural dimension and investigate possible differences and similarities in public administrations' decision making. Fourth, to interpret partial results concerning hypotheses $\mathrm{H}_{2}$ and $\mathrm{H}_{3}$, we did not control for a self-selection effect when comparing the decision making of law professionals and business professionals, which means that public servants with a business education would have a greater motivation to work in the public sector than their fellow students recruited by the private sector. Finally, past research by Kahneman et al. (1986a), Gorman and Kehr (1992), Haucap and Just (2010) and Faravelli (2007) showed that the framing of survey questions has a greater influence on respondents' choices than the background characteristics of their samples (i.e. control variables). In this context, it is important to consider that our study is the first to modify the survey questions of Kahneman et al. (1986a , b) and Rubinstein (2006) for a public-sector context. Although the empirical results of the pre-tests and the final survey make us confident that we have successfully avoided large distortions from the translation and modification of the original survey questions, we would appreciate future research that challenges our findings on comparable empirical grounds.

\section{Compliance with ethical standards}

Research involving human participants All procedures performed in studies involving human participants were in accordance with the ethical standards of the national research committee and with the 1964 Helsinki Declaration and its later amendments or comparable ethical standards.

Open Access This article is distributed under the terms of the Creative Commons Attribution 4.0 International License (http://creativecommons.org/licenses/by/4.0/), which permits unrestricted use, distribution, and reproduction in any medium, provided you give appropriate credit to the original author(s) and the source, provide a link to the Creative Commons license, and indicate if changes were made.

\section{Appendix}

See Tables 4, 5 and 6. 
Table 4 Adjustments to the original version of the Kahneman et al. (1986a) survey question, based on a real decision by the Kreisverwaltungsreferat der Landeshauptstadt München (2010)

Original version of the survey question of Kahneman et al. (1986a)

"A hardware store has been selling snow shovels for $\$ 15$. The morning after a large snowstorm, the store raises the price to $\$ 20$

Please rate this action as: completely fair, acceptable, unfair, or very unfair"
Modified version of the survey question used in the survey for this study

A city owns a carpark that is located right next to a congress hall. The city does not manage the parking garage by itself but relies on the services of a private firm. The contract between the city and the management of the carpark stipulates that the municipal council must approve all adjustments to the fee that it charges its users. Currently, the parking fee is set at 15 euros per day. In the upcoming week, a major event takes place in the congress hall. The management of the car park proposes to raise the fee from $€ 15$ to $€ 20$ during the event

Please assume the role of a senior official who faces the task of advising the municipal council on a temporary adjustment of the fee for a parking garage and rate this action as: completely fair, acceptable, unfair, or very unfair

Table 5 Adjustments to the original version of the Kahneman et al. (1986b) survey question based on a real decision by the HR Personal- und Organisationsreferat der Landeshauptstadt München (2014)

Original version of the survey question of Kahneman et al. (1986b)

"A football team normally sells some tickets on the day of their games. Recently, interest in the next game has increased greatly, and tickets are in great demand. The team owners can distribute the tickets in one of three ways. (1) By auction: the tickets are sold to the highest bidders. (2) By lottery: the tickets are sold to the people whose names are drawn. (3) By queue: the tickets are sold on a first-come first-served basis

Rank these three in terms of which you feel is the fairest and which is the least fair: the auction, the lottery, and the queue"
Modified version of the survey question used in the survey for this study

A city wants to sell land that can be used for construction sites. It announces that $50 \%$ of the available land will be sold to long-term residents, while the remainder will be offered to any interested party

Upon announcement of this news, the demand for the construction sites is much greater than the available supply

The municipal counsel discusses three resource allocation mechanisms by which it could distribute the scarce construction sites. (1) By auction: the construction sites are sold to the highest bidders. (2) By lottery: the construction sites are sold to people whose names are drawn first. (3) By queue: the construction sites are sold on a first-come, first-served basis

Please assume the role of a senior official who faces the task of advising the municipal council on the sale of the limited construction sites. Rank the aforementioned allocation mechanisms in terms of which you feel is the fairest and which is the least fair 
Table 6 Adjustments to the original version of the Rubinstein (2006) survey question based on a real decision by the Sozialreferat der Landeshauptstadt München (2014)

\begin{tabular}{|c|c|c|c|}
\hline \multicolumn{2}{|c|}{$\begin{array}{l}\text { Original version of the survey question of } \\
\text { Rubinstein (2006) }\end{array}$} & \multicolumn{2}{|c|}{$\begin{array}{l}\text { Modified version of the survey question used in } \\
\text { the survey for this study }\end{array}$} \\
\hline \multicolumn{2}{|c|}{$\begin{array}{l}\text { "Assume that you are vice president of ILJK } \\
\text { company. The company provides extermination } \\
\text { services and employs administrative workers who } \\
\text { cannot be fired and } 196 \text { non-permanent workers who } \\
\text { do the actual extermination work and can be fired. } \\
\text { The company was founded } 5 \text { years ago and is owned } \\
\text { by three families. The work requires only a low level } \\
\text { of skills so that each worker requires only one week } \\
\text { of training. All of the company's employees have } \\
\text { been with the company for three to five years. The } \\
\text { company pays its workers more than minimum wage. } \\
\text { A worker's wage, which includes overtime, amounts } \\
\text { to between NIS } 4,000 \text { and NIS } 5,000 \text { per month } \\
\text { [approx. } 790 € \text { - } 985 € \text {. The minimum wage in Israel } \\
\text { was about NIS } 3,335 / 660 € \text { at the time of the } \\
\text { experiment. The company provides its employees } \\
\text { with all the benefits required by law. } \\
\text { Until recently, the company was very profitable. As a } \\
\text { result of the continuing recession, however, there has } \\
\text { been a significant drop in profits, though the } \\
\text { company is still in the black. You will soon be } \\
\text { attending a meeting of the management at which a } \\
\text { decision will be made as to how many workers to lay } \\
\text { off. ILJK's Finance Department has prepared the } \\
\text { following forecast of annual profits: }\end{array}$} & \multirow{7}{*}{\multicolumn{2}{|c|}{$\begin{array}{l}\text { Assume that you are a senior official in your } \\
\text { hometown. As part of your position, you are } \\
\text { responsible for the muncipal service provider of } \\
\text { your city. The workforce of the municipal service } \\
\text { provider is in charge of many different tasks, which } \\
\text { range from garbage collection to the supply of fresh } \\
\text { water, and they include the management of the } \\
\text { theatre and swimming pool in your community. The } \\
\text { municipal service provider employs administrative } \\
\text { specialists who cannot be fired and } 196 \text { non- } \\
\text { permanent workers with fixed-term contracts. The } \\
\text { tasks of the employees with fixed-term contracts } \\
\text { require only a low level of skills such that each } \\
\text { worker requires only one week of training. All of the } \\
\text { employees of the municipal service provider have } \\
\text { been working for your city for three to five years. } \\
\text { The city pays its non-permanent employees a salary } \\
\text { in accordance with the collective agreement that } \\
\text { applies to all workers employed by the authorities of } \\
\text { the state in which your town is located. Furthermore, } \\
\text { your city provides its employees with all the benefits } \\
\text { required by law. } \\
\text { As a result of an economic recession, the profits of } \\
\text { the municipal service provider have deteriorated. } \\
\text { This development, in turn, has had a negative impact } \\
\text { on the budget of your city. The municipal counsel } \\
\text { discusses an opportunity to save money through a } \\
\text { reduction in the non-permanent workers employed by } \\
\text { the municipal service provider. You will soon be } \\
\text { attending a meeting of the municipal council at which } \\
\text { a decision will be made regarding the number of } \\
\text { workers to lay off. The finance department of your } \\
\text { city prepared the following forecast. }\end{array}$}} \\
\hline $\begin{array}{l}\text { Number of workers who will } \\
\text { continue to be employed }\end{array}$ & $\begin{array}{l}\text { Expected annual profit } \\
\text { in millions }\end{array}$ & & \\
\hline 0 (all workers will be laid off) & Loss of 8 & & \\
\hline 50 (146 workers will be laid off) & Profit of 1 & & \\
\hline 65 (131 workers will be laid off) & Profit of 1.5 & & \\
\hline 100 ( 96 workers will be laid off) & Profit of 2 & & \\
\hline 144 (52 workers will be laid off) & Profit of 1.6 & & \\
\hline 170 ( 26 workers will be laid off) & Profit of 1 & $\begin{array}{l}\text { Number of workers who will } \\
\text { continue to be employed }\end{array}$ & $\begin{array}{l}\text { Expected annual profit } \\
\text { in millions }\end{array}$ \\
\hline 196 (no layoffs) & Profit of 0.4 & 0 (all workers will be laid off) & Loss of 8 \\
\hline \multirow{7}{*}{\multicolumn{2}{|c|}{$\begin{array}{l}\text { I will recommend continuing to employ ___ of } \\
\text { the } 196 \text { workers in the company." }\end{array}$}} & 50 (146 workers will be laid off) & Profit of 1 \\
\hline & & 65 (131 workers will be laid off) & Profit of 1.5 \\
\hline & & 100 (96 workers will be laid off) & Profit of 2 \\
\hline & & 144 ( 52 workers will be laid off) & Profit of 1.6 \\
\hline & & 170 ( 26 workers will be laid off) & Profit of 1 \\
\hline & & 196 (no layoffs) & Profit of 0.4 \\
\hline & & \multicolumn{2}{|c|}{$\begin{array}{l}\text { I will recommend that the municipal council continue } \\
\text { to employ of the } 196 \text { workers who currently } \\
\text { work for the municipal service provider. }\end{array}$} \\
\hline
\end{tabular}




\section{References}

Alexander, C.S., and H.J. Becker. 1978. The use of vignettes in survey research. Public Opinion Quarterly 42 (1): 93-104.

Allinson, C.W., and J. Hayes. 1988. The learning styles questionnaire: An alternative to Kolb's inventory? Journal of Management Studies 25 (3): 269-281.

Amann, M., J.K. Roehrich, M. Eßig, and C. Harland. 2014. Driving sustainable supply chain management in the public sector: The importance of public procurement in the European Union. Supply Chain Management: An International Journal 19 (3): 351-366.

Ambrose, M.L., A. Arnaud, and M. Schminke. 2008. Individual moral development and ethical climate: The influence of person-organization fit on job attitudes. Journal of Business Ethics 77 (3): 323-333.

Aschhoff, B., and W. Sofka. 2009. Innovation on demand: Can public procurement drive market success of innovations? Research Policy 38 (3): 1235-1247.

Bandura, A. 1977. Social learning theory. Englewood Cliffs: Prentice Hall.

Blair, R., and C.L. Janousek. 2014. City management in the United States and Norway: A comparative analysis of professional orientations. International Journal of Public Administration 37 (8): 484-493.

Boltanski, L., and L. Thévenot. 2006. On justification: Economies of worth. Princeton: Princeton University Press.

Bright, L., and C.B. Graham. 2015. Why does interest in government careers decline among public affairs graduate students? Journal of Public Affairs Education 21 (4): 575-594.

Brosig, J., T. Heinrich, T. Riechmann, R. Schöb, and J. Weimann. 2010. Laying off or not? The influence of framing and economics education. International Review of Economics Education 9 (1): 44-55.

Broucker, B. 2010. Knowledge transfer of educational programs in public management: Transferinhibiting and transfer-enhancing factors in the belgian public sector. Journal of Public Affairs Education 16 (2): 231-253.

Broucker, B. 2015. Defining the impact of public administration programmes for public sector organizations. Teaching Public Administration 33 (2): 193-207.

Busz, M., R. Cohen, U. Poser, A. Schümer, R. Schümer, and C. Sonnenfeld. 1972. Die soziale Bewertung von 880 Eigenschaftsbegriffen sowie die Analyse der Ähnlichkeits-beziehungen zwischen einigen dieser Begriffe. Zeitschrift für experimentelle und angewandte Psychologie 19: 282-308.

Campbell, M.J., S.A. Julious, and D.G. Altman. 1995. Estimating sample sizes for binary, ordered categorical and continuous outcomes in two group comparisons. British Medical Journal 311 (7013): 1145-1148.

Capano, G. 2003. Administrative traditions and policy change: When policy paradigms matter. The case of Italian administrative reform during the 1990s. Public Administration 81 (4): 781-801.

Cavalluzzo, K.S., and C.D. Ittner. 2004. Implementing performance measurement innovations: Evidence from government. Accounting, Organizations and Society 29 (3-4): 243-267.

Cha, J., Y.K. Chang, and T.-Y. Kim. 2014. Person-organization fit on prosocial identity: Implications on employee outcomes. Journal of Business Ethics 123 (1): 57-69.

Christensen, T., and P. Lægreid. 2009. Living in the past? Change and continuity in the Central Civil Service. Public Administration Review 69 (5): 951-961.

Christensen, T., L. Dong, M. Painter, and R.M. Walker. 2012. Imitating the west? Evidence on administrative reform from the upper echelons of Chinese provincial government. Public Administration Review 72 (6): 798-806.

Cipriani, G.P., D. Lubian, and A. Zago. 2009. Natural born economists? Journal of Economic Psychology 30 (3): 455-468.

Clerkin, R.M., and J.D. Coggburn. 2012. The dimensions of public service motivation and sector work preferences. Review of Public Personnel Administration 32 (3): 209-235.

Cockerton, T., R. Naz, and S. Shepard. 2002. Factorial validity and internal reliability of honey and Mumford's learning style questionnaire. Psychological Reports 91 (2): 503-519.

Croson, R., and U. Gneezy. 2009. Gender differences in preferences. Journal of Economic Literature 47 (2): $448-474$.

Denhardt, R.B. 2001. The big questions of public administration education. Public Administration Review 61 (5): 526-534.

Deutsches Statistisches Bundesamt. (2013). Personal des öffentlichen Dienstes 2012. Wies-baden. 
Doherty, B., H. Haugh, and F. Lyon. 2014. Social enterprises as hybrid organizations: A review and research agenda. International Journal of Management Reviews 16 (4): 417-436.

Elazar, D.J. 1972. American federalism: A view from the states, 2nd ed. New York: Thomas Y. Crowell.

EU. 2004. Directive 2004/18/EC of the European Parliament and of the Council. http://eurlex.europa.eu/ LexUriServ/LexUriServ.do?uri_CELEX:32004L0018:en:NOT. Accessed 04 May 2017.

Faravelli, M. 2007. How context matters: A survey based experiment on distributive justice. Journal of Public Economics 91 (7): 1399-1422.

Festinger, L. 1957. A theory of cognitive dissonance. Stanford: Stanford University Press.

Frank, R.H. 2013. Microeconomics and behavior. New York: McGraw Hill.

Goossens, A., and P.G. Méon. (2010). "This is an economist's argument!" The impact of studying economics, and other disciplines, on the belief that voluntary transactions make everyone better off. Working paper for the Silvaplana Workshop in Political Economy at the University of Cambridge. Retrieved from the World Wide Web: http://www.solvay.edu/sites/upload/files/wp10012.pdf. Accessed 8 Aug 2018.

Gorman, R.F., and J.B. Kehr. 1992. Fairness as a constraint on profit seeking: Comment. The American Economic Review 82 (1): 355-358.

Grimmelikhujsen, S., and G.A. Proumbescu. 2017. Reconsidering the expectancy disconfirmation model. Three experimental replications. Public Management Review 19 (9): 1272-1292.

Hammerschmid, G., and R.E. Meyer. 2005. New public management in Austria: Local variation on a global theme? Public Administration 83 (3): 709-733.

Haucap, J., and T. Just. 2010. Not guilty? Another look at the nature and nurture of economics. European Journal of Law and Economics 29 (2): 239-254.

Kahneman, D., J.L. Knetsch, and R. Thaler. 1986a. Fairness as a constraint on profit seeking: Entitlements in the market. The American Economic Review 76 (4): 728-741.

Kahneman, D., J.L. Knetsc, and R. Thaler. 1986b. Fairness and the assumptions of economics. The Journal of Business 59 (4): S285-S300.

Katz, R. 2004. Organizational socialization and the reduction of uncertainty. In The human side of managing technological innovation: A collection of readings, 2nd ed, ed. R. Katz, 34-47. Oxford: Oxford University Press.

Kolb, D.A. 1981. Learning styles and disciplinary differences. In The Modern American College. Responding to new realities, ed. A.W. Chickering, 232-255. San Francisco: Jossey-Bass.

Kreisverwaltungsreferat der Landeshauptstadt München. (2010). Parkraummanagement in München. München: Landeshauptstadt München.

Kroll, A., and D.P. Moynihan. 2015. Does training matter? Evidence from performance management reforms. Public Administration Review 75 (3): 411-420.

Kuhlmann, S. 2010. New public management for the 'Classical Continental European Administration': Modernization at the local level in Germany, France and Italy. Public Administration 88 (4): 1116-1130.

Kuhlmann, S., J. Bogumil, and S. Grohs. 2008. Evaluating administrative modernization in german local governments: Success or failure of the "New Steering Model"? Public Administration Review 68 (5): 851-863.

Kuhlmann, S., and H. Wollmann. 2013. Verwaltung und Verwaltungsreformen in Europa. Wiesbaden: Springer.

Kunz, J., and S. Linder. 2012. Organizational control and work effort: Another look at the interplay of rewards and motivation. European Accounting Review 21 (3): 591-621.

Lanteri, A., and S. Rizzello. 2009. The economic way of thinking and the training of economists. International Journal of Social Sciences 3 (2): 161-168.

Liu, B., C. Hui, J. Hu, W. Yang, and X. Yu. 2011. How well can public service motivation connect with occupational intention? International Review of Administrative Sciences 77 (1): 191-211.

Ludwig-Maximilians-Universität München. 2008. Prüfungs- und Studienordnung der Ludwig-Maximilians-Universität München für den Bachelorstudiengang Betriebswirtschaftslehre. München: Ludwig-Maximilians-Universität München.

Ludwig-Maximilians-Universität München. 2012. Prüfungs- und Studienordnung der Ludwig-Maximilians-Universität München für den Studiengang Rechtswissenschaft mit dem Abschluss Erste Juristische Prüfung. München: Ludwig-Maximilians-Universität München.

Lüthje, C. 2008. Der Prozess der innovation. Tübingen: Mohr Siebeck.

Man, M.Z., X. Wang, and Y. Wang. 2000. POWER_SAGE: Comparing statistical tests for SAGE experiments. Bioinformatics 16 (11): 953-959. 
McPherson, C.M., and M. Sauder. 2013. Logics in action: Managing institutional complexity in a drug court. Administrative Science Quarterly 58 (2): 165-196.

Meyer, R.E., I. Egger-Peitler, M.A. Höllerer, and G. Hammerschmid. 2014. Of bureaucrats and passionate public managers: Institutional logics, executive identities, and public service motivation. Public Administration 92 (4): 861-885.

Meyer, R.E., and G. Hammerschmid. 2006. Changing institutional logics and executive identities: A managerial challenge to public administration in Austria. The American Behavioural Scientist 49 (7): 1000-1014.

Ng, E.S.W., and C.W. Gossett. 2013. Career choice in canadian public service: An exploration of fit with the millennial generation. Public Personnel Management 42 (3): 337-358.

Nitzl, C. 2016. The use of partial least squares structural equation modelling (PLS-SEM) in management accounting research: Directions for future theory development. Journal of Accounting Literature 37 : 19-35.

Olsen, A. L. 2017. Human interest or hard numbers? Experiments on citizens' selection, exposure, and recall of performance information. Public Administration Review 77(3): 408-420.

Ongaro, E., and G. Valotti. 2008. Public management reform in Italy: Explaining the implementation gap. International Journal of Public Sector Management 21 (2): 174-204.

Ossege, C. 2012. Accountability: Are we better off without it? An empirical study on the effects of accountability on public managers' work behavior. Public Management Review 14 (5): 585-607.

O'Toole, L.J., and K.J. Meier. 2015. Public management, context, and performance: In quest of a more general theory. Journal of Public Administration Research and Theory 25 (1): 237-256.

Pedersen, M.J. 2013. Public service motivation and attraction to public versus private sector employment: Academic field of study as moderator? International Public Management Journal 16 (3): 357-385.

Personal- und Organisationsreferat der Landeshauptstadt München. (2014). Übernahme des Personals des Textil- und Reinigungsservices (TRS) der Städtisches Klinikum München GmbH bei der Landeshauptstadt München. München: Landeshauptstadt München.

Pina, V., L. Torres, and A. Yetano. 2009. Accrual accounting in EU local governments: One method, several approaches. European Accounting Review 18 (4): 765-807.

Pollitt, C., and G. Bouckaert. 2017. Public management reform, a comparative analysis: Into the age of austerity, 4th ed. Oxford: Oxford University Press.

Püttner, G. 2007. Verwaltungslehre, 4th ed. München: Verlag C.H. Beck.

Raab-Steiner/Benesch. (2012). Der Fragebogen: Von der Forschungsidee zur SPSS-Auswertung, 3rd edition. Wien.

Rose, R.P. 2012. Preferences for careers in public work: Examining the government-nonprofit divide among undergraduates through public service motivation. The American Review of Public Administration 43 (4): 416-437.

Rubinstein, A. 2006. A Sceptic's comment on the study of economics. The Economic Journal 116 (510): C1-C9.

Sager, F., C. Rosser, P.Y. Hurni, and C. Mavrot. 2012. How traditional are the American, French and German traditions of public administration? A research agenda. Public Administration 90 (1): $129-143$.

Schein, Edgar H. 2003. Organizational socialization and the profession of management. In Organizational influence processes, ed. L.W. Porter, H.L. Angle, and Robert W. Allen, 283-294. New York: M.E. Sharpe.

Skelcher, C., and S.R. Smith. 2015. Theorizing hybridity: Institutional logics, complex organizations, and actor identities: The case of nonprofits. Public Administration 93 (2): 433-448.

Sozialreferat der Landeshauptstadt München. 2014. Grundsatzbeschluss zu Ausschreibung und Vergabe von städtischen Grundstücken für das Kommunale Wohnungsbauprogramm. München: Landeshauptstadt München.

Streukens, S., and S. Leroi-Werelds. 2016a. Bootstrapping and PLS-SEM: A step-by-step guide to get more out of your bootstrap results. European Management Journal 34 (6): 618-632.

Streukens, S., and S. Leroi-Werelds. 2016b. PLS FAC-SEM: An illustrated step-by-step guideline to obtain a unique insight in factorial fata. Industrial Management and Data Systems 116 (9): 1922-1945.

Taylor, B.J. 2006. Factorial surveys: Using vignettes to study professional judgment. British Journal of Social Work 36 (7): 1187-1207.

Vandenabeele, W. 2008. Government calling: Public service motivation as an element in selecting government as an employer of choice. Public Administration 86 (4): 1089-1105. 
Van de Walle, S., and T. Bovaird. 2007. Making better use of information to drive improvement in local public services. A report for the audit commission. Birmingham: University of Birmingham.

Veit, S., and S. Scholz. 2016. Linking administrative career patterns and politicization: Signalling effects in the careers of top civil servants in Germany. International Review of Administrative Sciences 82 (3): 516-535.

Walker, R.M., G.A. Brewer, B. Bozeman, M.J. Moon, and J. Wu. 2013. An experimental assessment of public ownership and performance. Comparing perceptions in East Asia and the United States. Public Management Review 15 (8): 1208-1228.

Wallander, L. 2009. 25 years of factorial surveys in sociology: A review. Social Science Research 38 (3): 505-520.

Weber, M. (1922/1978). Economy and society: An outline of interpretive sociology. University of California Press, Los Angeles.

Witesman, E.M., and C.R. Wise. 2012. The reformer's spirit: How public administrators fuel training in the skills of good governance. Public Administration Review 72 (5): 710-720.

Wright, B.E., S. Hassan, and R.K. Christensen. 2017. Job choice and performance: Revisiting core assumptions about public service motivation. International Public Management Journal 17 (1): $108-131$.

Ziller, J. 2012. The continental system of administrative legality. In The SAGE handbook of public administration, 2nd ed, ed. J. Pierre and B.G. Peters, 260-268. London: Sage Publications Limited.

\section{Legal sources}

German Judiciary Act, in the version of June 8, 2017. (2017). Retrieved from the World Wide Web: http://www.gesetze-im-internet.de/englisch_drig/index.html. Accessed 8 Aug 2018.

Bayerische Ausbildungs- und Prüfungsordnung für Juristen (in German), in the version of June 14, 2017. (2018). Retrieved from the World Wide Web: https://www.justiz.bayern.de/landesjustizpruefung samt/ausbildungs-pruefungsordnung/. Accessed 8 Aug 2018.

Publisher's Note Springer Nature remains neutral with regard to jurisdictional claims in published maps and institutional affiliations. 